\title{
KONSTRUKSI MODEL WAKAF PERUSAHAAN DALAM NEGARA HUKUM INDONESIA
}

\author{
Miftahul Huda, Lukman Santoso \\ Institut Agama Islam Negeri Ponorogo I Jl. Puspita Jaya, Krajan, Pintu, Kec. \\ Jenangan, Kabupaten Ponorogo | \\ lukmansantoso4@gmail.com
}

\begin{abstract}
This study aims to explore the model of management and development of company waqf assets in Malaysia and Singapore, and their relevance to the development of company waqf construction in accordance with Indonesian waqf law and the wisdom of traditions that have developed. By using an interpretive explorative type qualitative approach, this research resulted in the finding, that the construction of the management model and development of corporate waqf assets in Indonesia in accordance with the context of Indonesian waqf law and traditional wisdom are business entities, banks, universities, foundations, hospitals, cooperative. So as to realize the strengthening of the holistic corporate waqf model in Indonesia, it is necessary to strengthen the regulatory stakeholders as well as an integrative and holistic understanding among scholars.
\end{abstract}

Keywords: construction model of waqf; corporation waqf.

Abstrak: Penelitian ini bertujuan untuk menggali model pengelolaan dan pengembangan aset-aset wakaf perusahaan di Malaysia dan Singapura, serta relevansinya bagi pengembangan konstruksi wakaf perusahaan yang sesuai dengan hukum wakaf Indonesia dan kearifan tradisi yang telah berkembang. Dengan menggunakan metode pendekatan kualitatif tipe eksploratif interpretatif, penelitian ini mengasilkan temuan, bahwa konstruksi model pengelolaan dan pengembangan aset-aset wakaf perusahaan di Indonesia yang sesuai dengan konteks hukum wakaf Indonesia dan kearifan tradisi adalah badan usaha, bank, universitas, yayasan, rumah sakit, koperasi. Sehingga untuk mewujudkan penguatan model wakaf korporasi holistik di Indonesia diperlukan penguatan pada pemangku regulasi sekaligus pemahaman yang integratif dan holistik di kalangan ulama.

Kata kunci: konstruksi model wakaf; wakaf korporasi. 


\section{Pendahuluan}

Sebagaimana diutarakan Miriam Hoexter, ${ }^{1}$ dari berbagai bentuk filantropi Islam, yaitu zakat, infak sedekah, dan wakaf, hanya wakaf yang menjadi institusi-institusi hukum yang berkembang secara penuh. Di antara lembaga sosial dalam Islam tersebut, sepanjang sejarah Islam, wakaf telah memegang peranan yang sangat penting dalam mengembangkan kegiatan-kegiatan sosial, ekonomi, dan kebudayaan masyarakat Islam. Kenyataan ini menunjukan, institusi wakaf telah banyak menjalankan sebagian dari fungsi dan tugas pemerintah. ${ }^{2}$ Sebagai contoh dapat dijumpai di negara Mesir, ${ }^{3}$ dengan wakaf yang dikembangkan dalam berbagai bentuk, maka banyak manfaat yang dapat dilakukan dari hasil wakaf tersebut. Perguruan tinggi yang ternama di Kairo, yaitu Universitas Al Azhar sejak tahun 970 M sampai sekarang dibiayai oleh pengelolaan harta hasil wakaf. ${ }^{4}$ Mahasiswa dari luar Mesir, yang jumlahnya mencapai ribuan dan belajar di universitas tersebut juga memperoleh beasiswa dari hasil wakaf tersebut.

Salah satu konsep wakaf kontemporer dikenal sebagai wakaf perusahaan. Wakaf perusahaan biasanya dianggap sebagai komponen wakaf uang. Namun, perkembangan baru bahwa wakaf perusahaan harus ditetapkan sebagai konsep wakaf mandiri. ${ }^{5}$ Artinya wakaf perusahaan sebagai kategori wakaf independen karena karakteristik yang menonjol dan memperluas pemahaman dan konsep perusahaan wakaf terkini. Realitas

\footnotetext{
I Miriam Hoexter, Charity, The Poor, and Distribution of Alms in Ottomon Algiers, dalam Tuti A. Najib dan Ridwan al-Makassary, ed., Tuhan, dan Agenda Kemanusiaan, Studi Tentang Wakaf dalam Perspektif Keadilan Sosial di Indonesia, (Jakarta: Center for the Study of Religion and Culture (CSRS) Universitas Islam Negeri Syarif Hidayatullah, Desember 2006), xiii.

2 Kementerian Agama Negara RI, Paradigma Baru Wakaf di Indonesia, (Jakarta: Direktorat Pemberdayaan Wakaf, 2008), 10.

3 "Wakaf di Singapura dan Mesir", dalam Majalah Sharing, Edisi 52, Thn V, (April 201 I): 19.

${ }^{4}$ Kementerian Agama Negara RI, Model Penggembangan Wakaf Produktif, (Jakarta; Direktorat Wakaf, 2008), 33.

${ }^{5}$ Asharaf Mohd Ramli, \& Abdullaah Jalil. "Corporate Waqf Model and Its Distinctive Features: The Future of Islamic Philanthropy" (2013, 4 - 5 December), 2.
} 
menunjukkan bahwa upaya untuk meremajakan institusi wakaf di negara-negara Islam diikuti oleh entitas perusahaan.

Wakaf perusahaan telah dipraktikkan di sejumlah negara Muslim modern, yaitu; Turki, Singapura, Malaysia, Bangladesh, India dan Pakistan. Partisipasi perusahaan dalam membangun dan mengelola aset wakaf telah dimulai di Pakistan, Singapura dan Turki sebelumnya. ${ }^{6}$ Keterlibatan badan perusahaan ke dalam kegiatan wakaf mulia ini menunjukkan dimensi etika dunia usaha.

Di Malaysia melalui Johor Corporation (JCorp) telah memulai sebuah usaha wakaf pada tahun 1998 yang kemudian berkembang menjadi entitas wakaf perusahaan yang dikenal dengan Waqaf An-Nur Corporation Berhad (WANCorp). Melalui skim wakaf ini Johor Corporation Berhad (JCorp) menjadikan implementasi program CSR mereka melalui Waqf An Nur Corporation Berhad.7 Demikian pula Singapura, wakaf produktif berbasis korporasi dikembangkan Majelis Ugama Islam Singapura (MUIS). Seluruh properti wakaf MUIS dikelola oleh Warees Investments Pte Ltd, perusahaan real estate yang sahamnya 100 persen dimiliki MUIS. Warees berhasil membangun 20 unit perumahan Wakaf Kassim, termasuk sebuah bangunan komersial dan institusi pendidikan Wisma Indah di Changi Road. Wakaf Kassim setiap tahunnya memperoleh keuntungan dari hasil sewa Wisma Indah $\$ \$ 300.000 .-.8$

Dalam konteks Indonesia, penelitian yang dilakukan oleh Ascarya menyebut terdapat model-model wakaf produktif paling aplikatif di Indonesia, sesuai dengan UU No. 41 Tahun 2004 tentang wakaf. Penelitian tersebut membagi model wakaf menjadi dua bagian utama, yakni model wakaf sederhana dan model wakaf

\footnotetext{
${ }^{6}$ Magda Ismail Abdel Mohsin. Cash Waqf: A New Financial Product, (Petaling Jaya: Prentic HallPearson, 2009).

${ }^{7}$ Asharaf Mohd Ramli, \& Abdullaah Jalil. "Corporate Waqf Model and Its Distinctive Features: The Future of Islamic Philanthropy". (2013, 4 - 5 December), 9.

${ }^{8}$ Muhammad Abbas Aula, "Artikel Pemberdayaan Umat Melalui Lembaga Wakaf,"

http://bwi.or.id/index.php?, diakses I 4 Agustus 20 17. Lihat pula Sulaeman, "Model Investasi Wakaf Melalui Sukuk Musyarakah: Studi Kasus Negara Singapura", Forum Riset Ekonomi dan Keuangan Syariah IV (20 I 5), 2 I7-2 I 8
} 
inovatif. Ascarya memaparkan, dari 172 model wakaf sederhana dan 106 lebih model wakaf inovatif yang berkembang di dunia, ada 10 model wakaf sederhana dan 6 model wakaf inovatif yang dinilai paling aplikatif untuk diterapkan di Indonesia. ${ }^{9}$

Dua model wakaf sederhana yang paling aplikatif di Indonesia antara lain Cash Waqf and Self-Managed (menggalang wakaf melalui uang dan nazhir mengelola sendiri) dan Cash Waqf and External Management (menggalang wakaf uang dan dikelola pihak lain). Sementara itu, model wakaf inovatif belum diterapkan di Indonesia, mengingat bentuknya yang cenderung rumit dengan melibatkan lebih dari lima pemangku kepentingan. Namun demikian, beberapa model wakaf inovatif akan diterapkan di Indonesia beberapa bulan ke depan. Misalnya saja, model BOT by PC/SOC \& International Financing (Built-operate-transfer dengan perusahaan swasta dan pembiayaan internasional) yang diterapkan oleh Global Wakaf Foundation bersama dengan Yayasan Raudhatul Muta'allimin, Provera, dan IDB. ${ }^{10}$

Distingsi penelitian ini, dengan menggali comparative advantage, berupaya melakukan perbandingan pengelolaan wakaf berbasis korporasi di Asia Tenggara, khususnya Malaysia dan Singapura untuk dapat dijadikan model pengembangan wakaf di Indonesia, sehingga diharapkan dapat memberikan kontribusi yang berarti bagi pengembangan aset-aset wakaf di Indonesia melalui korporasi atau perusahaan untuk kesejahteraan masyarakat luas. Berangkat dari latar belakang di atas, artikel ini akan memfokuskan kajian pada bagaimana rancangan model-model pengembangan wakaf perusahaan untuk Indonesia yang sesuai dengan konteks hukum wakaf Indonesia dan kearifan tradisi yang telah berkembang?

${ }^{9}$ Ascarya, "Merancang Model-model Wakaf Produktif"., https://archive.act.id/id., akses, 20 Agustus 2017.

${ }^{10} \mathrm{lbid}$. 


\section{Pembahasan}

Wakaf dalam perkembangannya telah terbukti menjadi insitusi filantropi Islam yang berkembang baik secara teoretis maupun praktis. Munculnya aset wakaf bergerak, terutama dalam bentuk saham perusahaan dan uang tunai yang diterapkan di sejumlah negara Muslim juga mempengaruhi praktik wakaf perusahaan di berbagai negara.

Wakaf perusahaan secara sederhana juga dipahami sebagai pengelolaan aset-aset wakaf dan pembagian hasil wakaf oleh badan usaha baik secara independen ataupun kerjasama dengan pihak lain. Definisi ini dapat diuraikan lebih jauh ke dalam empat hal utama, yaitu: aset wakaf dan pengelolaan wakaf, pembagian wakaf dilanjutkan, entitas perusahaan, dan Independen atau kerjasama dengan pihak lain. ${ }^{11}$

Pada tahap pertama wakaf perusahaan, entitas perusahaan akan menciptakan aset wakaf sendiri dengan menggunakan asetnya sendiri. Dalam situasi ini, entitas perusahaan dalam pembuat wakaf atau al-waqif itu sendiri. Aset wakaf dapat berupa aset keuangan seperti kas atau saham atau aset non-keuangan seperti bangunan atau tanah. Pada saat bersamaan, badan usaha mencalonkan dirinya sebagai wali amanat yang bertanggung jawab mengelola, memelihara dan menginvestasikan aset wakaf. Ini berarti bahwa entitas perusahaan juga merupakan nazir atau mutawalli dari aset wakaf. ${ }^{12}$

Entitas perusahaan kemudian dapat mencalonkan dirinya sebagai satu-satunya penerima manfaat atau salah satu penerima manfaat dari wakaf tersebut agar memiliki fleksibilitas dalam mengelola dan memanfaatkan hasilnya. Ini dikenal dalam yurisprudensi Islam sebagai al-Waqf 'ala al-Waqif atau wakaf dibuat

\footnotetext{
" Johor Corporation. Johor Corporation: Corporate Waqf Concept (Konsep Waqaf Korporat), Johor Bahru: Johor Corporation \& Kumpulan Waqaf An-Nur Berhad, (2008), 25.

${ }^{12}$ Asharaf Mohd. Ramli, \& Abdullaah Jalil, "Banking Model of Corporate Waqf: An Analysis of Wakaf Selangor Muamalat", Paper presented at the International Accounting and Business Conference (IABC), Persada Johor, Johor Bahru, (20।3).
} 
oleh pemilik/ pemilik itu sendiri. ${ }^{13}$ Praktik ini telah diizinkan oleh beberapa ahli hukum Islam. ${ }^{14}$ Setelah menerima hasilnya, mereka kemudian didistribusikan ke penerima manfaat akhir dan nyata seperti orang miskin dan orang miskin, institusi Islam dan sebagainya. Pengaturan ini memberikan keleluasaan kepada entitas perusahaan untuk pengelolaan dan pemanfaatan hasil produktivitas wakaf. Fleksibilitas semacam itu sangat penting untuk menarik lebih banyak partisipasi dari entitas perusahaan ke dalam praktik wakaf perusahaan. Ini berarti bahwa entitas perusahaan dapat mengatur dan merencanakan penyaluran dana secara kreatif dan produktif berdasarkan kebutuhan entitas dan masyarakat pada saat penyaluran dana. Jika kondisi ekonomi buruk di mana entitas perusahaan menemukan dirinya dalam kondisi keuangan yang sulit, mereka dapat menggunakan dana wakaf tersebut untuk dirinya sendiri dan mereka tidak diwajibkan untuk mendistribusikannya. Aspek wakaf perusahaan ini akan memasukkan unsur kepentingan bisnis ke dalam konsep amal wirausaha (tabarru) wakaf.

Wakaf Perusahaan didirikan oleh keseluruhan pribadi yang terlibat dalam kegiatan menghasilkan pendapatan seperti perdagangan dan investasi. Entitas ini juga diharuskan menerapkan etika tata kelola perusahaan terhadap akuntabilitas, transparansi dan profesionalisme dalam mengakumulasi dan mendistribusikan aset wakaf. Sesuai dengan struktur hukum negara, badan usaha dapat secara mandiri mendirikan, mengelola dan mendistribusikan hasil wakaf kepada penerima manfaat.

Tan Sri Ali Hasyim menguraikan enam model wakaf perusahaan yang bisa terstruktur antara lain, (i) badan usaha atau perusahaan, (ii) lembaga perbankan dan keuangan, (iii) universitas, (iv) yayasan, (v) koperasi, dan (vi) rumah sakit atau klinik. Ada beberapa pertimbangan dalam memeriksa wakaf perusahaan dari sudut pandang fikih wakaf. Pertimbangannya adalah sebagai

\footnotetext{
13 Jamal, Ahmad Muhammad 'Abd al-Azim., Daur Nizam Al Waqf al-Islami fi Tanmiyah allqtishadiyah al Mu'ashirah, (Qahirah: Dar as-Salam, 2007), 102.

${ }^{14}$ Ibid., I 22.
} 
berikut: shakhsiyyah i'tibariyyah baik ahliyyah (kapasitas hukum) ataupun wilayah (otoritas hukum), waqf al-waqif pada dirinya sendiri, al-waqif menetapkan untuk dirinya sendiri, waqf hybrid (waqf mushtarak) atau kombinasi waqf khayri dan waqf ahli/dhurri, dan pertimbangan istibdal. ${ }^{15}$

Wakaf perusahaan mengacu pada penyerahan harta seperti uang tunai, saham, keuntungan dan dividen oleh pewakaf yang terdiri dari individu, perusahaan, korporasi, organisasi atau lembaga serta penyaluran manfaat secara berkelanjutan untuk kemaslahatan masyarakat. ${ }^{16}$

Definisi ini memberikan konotasi bahwa wakaf perusahaan jika dilihat dari sudut aset adalah merupakan bagian dari wakaf tunai, yaitu pewakaf mewakafkan harta tidak bergerak seperti uang tunai, saham, keuntungan dan juga dividen. Penyerahan aset seperti saham, laba dan dividen biasanya dapat dilakukan oleh perusahaan dan perusahaan.

Asharaf dan Abdullah, ${ }^{17}$ juga memberikan definisi wakaf perusahaan sebagai pembentukan dan pengelolaan aset wakaf serta penyaluran manfaat wakaf oleh sebuah badan perusahaan secara sendirian ataupun melalui kerjasama dengan pihak-pihak lain. Melalui definisi ini, pihak badan perusahaan akan terlibat secara langsung di dalam ketiga aspek pembentukan aset wakaf, manajemen aset wakaf dan juga penyaluran manfaat wakaf kepada penerima-penerima yang telah ditentukan berdasarkan argumen wakaf. Ada empat fitur utama wakaf perusahaan yaitu pembentukan dan pengelolaan aset wakaf, penyaluran manfaat wakaf, pewakaf yang terdiri dari badan perusahaan, dan juga

\footnotetext{
${ }^{15}$ Asharaf Mohd Ramli, \& Abdullaah Jalil. "Corporate Wagf Model and Its Distinctive Features: The Future of Islamic Philanthropy". (2013, 4 - 5 December). 6.

${ }^{16}$ Magda Ismail Abdel Mohsin. Corporate Waqf And Its Role In The Different Societies, The 2nd Internationa/Conference on Islamic Economics and Economies of the OIC Countries (ICIE 20/3) (Kuala Lumpur. 20I3).

${ }^{17}$ Asharaf Mohd Ramli dan Abdullaah Jalil, Funding Higher Education In Malaysia: Corporate Waqf Model, Waqf Workshop: Contemporary Role of Higher Education, Alor Star: Al-Bukhari International University. (2013)
} 
keterlibatan badan perusahaan secara sendirian ataupun dengan kerjasama pihak-pihak lain.

Awqaf Holdings, sebagai sebuah entitas wakaf korporasi pula telah menggunakan terminologi waqaf korporat untuk menerangkan konsep wakaf perusahaan yang diperkenalkannya sebagaimana yang terkandung di dalam Memorandum Awqaf. Menurut Memorandum AWQAF, waqaf perusahaan mengacu kepada sebuah perusahaan, yaitu organisasi perusahaan bersumber dana wakaf kontribusi masyarakat, bertujuan untuk diinvestasikan ke dalam bisnis yang menguntungkan, sehingga semua keuntungan dan pertambahan nilai dijadikan aset wakaf milik kekal AWQAF. Dari definisi ini, waqaf korporat mengacu pada perusahaan yang dibentuk untuk mengelola dana wakaf dan kemudian menyalurkannya kepada penerima. Ada delapan karakteristik wakaf perusahaan yang telah digariskan yaitu, pembentukan perusahaan, Mutawalli, diberi kekuasaan, praktik korporasi terbaik, mengumpulkan dan melestarikan sumber, kewirausahaan, keterlibatan dalam dan prinsip syariah. ${ }^{18}$

Dari ketiga definisi ini ada beberapa kesamaan, seperti aset wakaf perusahaan yang terdiri dari aset keuangan seperti uang tunai, saham, laba dan dividen. Dari aspek manajemen pula asetaset wakaf yang didirikan akan dikelola oleh badan perusahaan yang juga bertanggung jawab untuk menyalurkan manfaat wakaf kepada penerima.

Penjelasan konseptual pertimbangan fikih tentang wakaf perusahaan adalah sebagai berikut: Pertama, Shakhsiyyah I'tibariyyah: Ahliyyah (Kapasitas Hukum) dan Wilayah (Otoritas Hukum). Dalam konsep hukum wakaf, donor biasanya adalah individu alami (shakhsiyyah haqiqiyyah atau tabiiyyah). Namun, dalam praktik wakaf perusahaan, donor biasanya merupakan institusi. Dengan demikian, konsep hukum individu atau entitas (shakhsiyyahi'tibariyyah/ qanuniyyah/ma'nawiyyah) mungkin timbul. Namun, karena sebagian besar ahli hukum Islam kontemporer telah

18 Memorandum AWQAF dan Ciri-ciri Waqaf Korporat, awqaf.com..my. diakses pada 6 Agustus 2018. 
sepakat untuk mengenali konsep ini berdasarkan analogi dengan bayt al-mal, dan masjid, masalahnya mungkin dianggap telah diselesaikan. Namun, dua persyaratan terpenting yang harus dinikmati oleh perwakilan dari shakhsiyyah i'tibariyyah ini adalah ahliyyah (legal capacity) dan wilayah (legal authority). Persyaratan kedua berarti bahwa donor harus menjadi pemilik materi pokok atau agen (wakil) yang ditunjuk oleh pemilik yang melakukan kontrak berdasarkan kontrak wakalah (agensi). Masalah ini mungkin lebih penting jika perusahaan - yang berencana membuat skema perusahaan wakaf sendiri - dimiliki oleh pemerintah dan bukan oleh individu. ${ }^{19}$

Kedua, Waqf al-Waqif pada dirinya sendiri. Umumnya, praktik wakaf dimaksudkan untuk amal dan qurbah. Oleh karena itu, mayoritas ahli hukum Islam menyatakan bahwa kepemilikan wakaf seharusnya tidak kembali ke waqif sendiri karena menolak tujuan wakaf. Namun, berdasarkan analisis penulis, beberapa praktik perusahaan wakaf mencalonkan waqif dirinya sebagai pemilik sah wakaf. Para ahli hukum Islam mengenai masalah ini memandang bahwa hal ini tidak benar karena wakaf tidak dapat kembali memiliki dirinya sendiri apa yang telah dimilikinya. ${ }^{20}$ Penulis menyukai pendapat sehubungan dengan praktik wakaf perusahaan karena institusi tersebut biasanya tidak bermaksud untuk menata ulang aset wakaf. Praktik semacam itu dilakukan untuk memberi fleksibilitas dan hak penuh lembaga korporasi dalam mengelola, mendistribusikan dan menyalurkan hasil wakaf atau bahkan memanfaatkannya. Lembaga tersebut dapat menggunakan dana wakaf perusahaan untuk program CSR mereka dan dalam situasi tertentu menggunakan kembali dana tersebut untuk mempertahankan operasi dan bisnis mereka. Fleksibilitas ini akan memberi mereka motivasi yang lebih besar untuk terlibat dalam praktik wakaf perusahaan dan menyediakan lebih banyak ruang

\footnotetext{
19 Abdullah Jalil \& Asharaf Mohd Ramli, "Conceptualisation of Corporate Waqf" (2014), http://ddms.usim.edu.my. 318, Akses pada 20 Agustus, 2018.

${ }^{20}$ Al-Kabisi, Muhammad Abid Abdullah., (2004), Hukum Wakaf, (Jakarta: IIMaN Press), 56.
} 
untuk kepatuhan Syariah. Namun pendapat ini secara hukum bertentangan dengan kerangka hukum yang ada. ${ }^{21}$

Ketiga, Waqif Menetapkan untuk dirinya sendiri. Gagasan lain yang mungkin serupa dengan situasi sebelumnya adalah situasi di mana wakaf menetapkan dirinya sebagai satu-satunya penerima manfaat atau penerima manfaat utama atau di antara penerima manfaat dari hasil wakaf tersebut. Hanabilah, Hanafiyyah dan pendapat Shafiiyyah memandang praktik semacam itu sebagai tindakan yang diijinkan untuk mendorong orang membuat dukun dan berdasarkan beberapa bukti Syari'ah. Di sisi lain, Shafi'iyyah dan Muhammad Ibn al Hasan dari Hanafiyyah memandang praktik seperti itu umumnya tidak dapat dipungkiri dengan pengecualian tertentu. ${ }^{22}$

Keempat, Hybrid Waqf (Waqf Mushtarak): Kombinasi Waqf Khayri dan Wakaf Ahli / Dhurri. Dalam hal penerima manfaat, wakaf bisa berupa wakaf khayri (wakaf amal) atau wakaf ahli/dhurri (anugerah untuk keturunan). ${ }^{23}$ Berdasarkan praktik perusahaan wakaf, telah diamati bahwa beberapa institusi menetapkan dirinya atau anak perusahaan mereka sebagai penerima manfaat utama dari wakaf tersebut. Sebagaimana dibahas di atas, ada beberapa ahli hukum Islam dan pendapat yang menyetujui praktik semacam itu. Dari perspektif fikih, perpaduan antara waqf khayri dan waqf dhurri dikenal sebagai waqf mushtarak. Dari perspektif manajerial, waqf mushtarak bisa memberi keuntungan bagi institusi yang terlibat dalam wakaf perusahaan. Lembaga ini dapat merancang skema wakaf perusahaannya agar sejalan dengan program CSR-nya. Dengan demikian, praktik program wirausaha dan CSR wakaf dapat dibangun bersama sebagai pasangan.

Kelima, Istibdal. Gagasan istibdal sangat penting untuk kelangsungan dan keberlanjutan perusahaan wakaf. Meskipun praktik istibdal telah disetujui oleh beberapa ahli hukum Islam

\footnotetext{
21 Abdullah Jalil \&Asharaf Mohd Ramli, "Conceptualisation of Corporate Waqf" (20|4), http://ddms.usim.edu.my. hlm. 320.

22 lbid., 322.

${ }^{23}$ Miftahul Huda, Mengalirkan Manfaat Wakaf, (Depok: Gramata Publishing, 20 I5), 46.
} 
dengan kondisi tertentu, masalah ini dapat dikaji ulang secara rinci untuk memastikan kepatuhan terhadap praktik istibdal. Model wakaf perusahaan yang dipelopori dan dipraktikkan dengan melakukan praktik istibdal yaitu penggantian aset wakaf dengan yang sejenis. Praktik istibdal didasarkan pada nilai (pasar) saham dan bukan kuantitas (unit) saham. Praktik ini telah menjadi alternatif bagi praktik istibdal bila diperlukan di masa depan. ${ }^{24}$

\section{Konstruksi Tawaran Model Corporate Waqf Untuk Indonesia Model CW Berbasis Bisnis Keuangan}

Dalam praktik wakaf produktif di Indonesia, sebenarnya secara embrionik sudah tumbuh bisnis keuangan berbasis wakaf, namun belum menjadi gerakan yang terskema secara komprehensif dalam bentuk model bisnis korporasi yang integral, baik tata kelolanya, penghimpunannya maupun distribusinya seperti halnya di Turki atau Malaysia. Namun masih sebatas inisiatif dan kreatifitas masing-masing lembaga.

Sebuat saja misalnya, Baitul Maal Muamalat (BMM). Ini adalah Lembaga Amil Zakat, Infak, dan Sedekah (LAZIS) yang bernaung di bawah Bank Muamalat Indonesia (BMI). Pada awalnya, BMM didirikan sebagai lembaga yang menerima dana ZIS dari lingkungan BMI untuk selanjutnya didistribusikan kepada masyarakat miskin dan pemberdayaan usaha mikro. Pada tahun 2002, BMM meluncurkan program Wakaf Tunai Muamalat (Waktumu) sebagai produk pengelolaan wakaf uang. Penghimpunan dana BMM dilakukan melalui pemindahbukuan dari rekening nasabah BMI yang ingin mewakafkan sejumlah uang tabungan. Investasi BMM dari dana wakaf uang lebih banyak menyentuh sektor keuangan, salah satunya dengan skema bagi hasil pada Baitul Maal wat Tamwiil (BMT).

Contoh lainnya, Gedung Raudha, yang berdiri di atas tanah bersertifikat wakaf atas nama nazhir, Yayasan Raudhatul Muta'allimin (YRM) dan letaknya sangat strategis di Jalan Raya

${ }^{24}$ Al-Kabisi, Muhammad Abid Abdullah., Hukum Wakaf, (Jakarta: IIMaN Press, 2004), hlm. 67. 
H.R. Rasuna Said dan Jalan Kuningan Barat Raya. YRM pada awalnya membangun gedung Raudha dengan dana sendiri. Karena kekurangan dana dilakukan kerja sama selama enam tahun (2004 2010) dengan investor. Pihak investor menyelesaikan pembangunan gedung dan sebagai kompensasinya berhak atas keuntungan dari penyewaan gedung tersebut. Selanjutnya, pada tahun 2013, YRM (nazhir) bekerja sama dengan investor lain untuk membangun gedung perkantoran komersial, dengan luas tanah \pm $4.000 \mathrm{~m} 2$. Kerjasama ini menggunakan skema built, operate, and transfer (BOT). Investor membiayai pembangunan gedung dan menggunakannya selama 35 tahun. Setelah itu kepemilikan dan pengelolaan gedung diserahkan kepada nazhir. Nazhir juga memperoleh kompensasi uang sewa sebesar Rp1,2 miliar per tahun. ${ }^{25}$

Berbeda dengan praktik model wakaf bisnis keuangan di Malaysia misalnya, yang dipraktikkan melalui Bank Muamalat Malaysia Berhad (BMMB) pada September 2012 bekerjasama dengan Perusahaan Wakaf Selangor (PWS) memperkenalkan skema wakaf tunai yang dikenal sebagai Wakaf Selangor Muamalat. Melalui kerjasama ini, BMMB dan PWS adalah merupakan manajer bersama aset wakaf yang diperoleh melalui pembelian sertifikat wakaf tunai yang dapat dilakukan di setiap cabang BMMB. Selain itu, kontribusi wakaf juga dapat dilakukan melalui internet banking, pemotongan bulanan dan instruksi pembayaran berkala. ${ }^{26}$ Dalam hal distribusi manfaat wakaf, umumnya masyarakat, penerima wakaf berasal dari sektor pendidikan, kesehatan, agama dan sosial. Di antara penerima seperti mushola, masjid, sekolah dan juga indidvidu untuk menutupi biaya kesehatan dan pendidikan. Laporan pengumpulan dan distribusi manfaat wakaf disampaikan setiap tiga bulan untuk memfasilitasi para pemangku kepentingan (stakeholders) untuk memperoleh informasi rinci tentang wakaf secara rinci.

\footnotetext{
25 BWI, 2016.

${ }^{26}$ BBMB, 2012.
} 
Praktik model wakaf korporat institusi perbankan dan keuangan, program wakaf yang dijalankan secara usaha bersama antara Bank Muamalat Malaysia Berhad (BMMB) dan Perbadanan Wakaf Selangor (PWS), ini setidaknya dapat menjadi model dalam pengembangan bisnis wakaf keuangan yang lebih komprehensif di Indonesia. Bagan model dapat dilihat pada skema berikut:

\section{Gambar Model Wakaf Korporasi Perbankan}

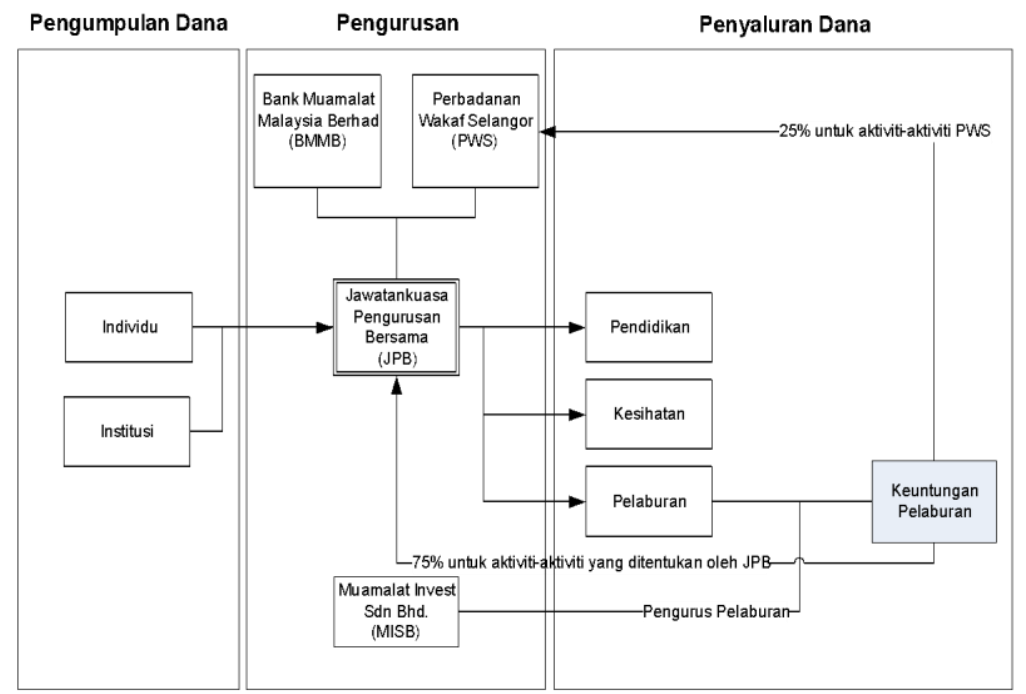

Sumber : Modifikasi dari Asharaf \& Abdullaah, 2014.

Dana wakaf diperolehi melalui sumbangan individu dan juga institusi yang boleh mendepositkan uang tunai sebagai aset wakaf di seluruh cabang Bank Mumalat seluruh Malaysia. Sumbangan wakaf minimal bagi individu sejumlah RM10, bagi institusi berjumlah RM100 dan tidak ada batas jumlah maksimalnya. Pihak pengelola dana wakaf ini berharap untuk mengumpulkan sejumlah RM50 juta dalam tempoh tiga tahun dan inisiatif ini dimulakan dengan sumbangan wakaf daripada Bank Muamalat berjumlah RM1 juta dan kakitangannya yang berjumlah RM74, 040 sewaktu 
majlis pelancaran Wakaf Selangor Muamalat. ${ }^{27}$ Dana wakaf yang dikumpulkan akan disalurkan oleh JPB kepada penerima-penerima daripada tiga sektor utama seperti di bawah:

1. Pendidikan contohnya pembinaan bangunan sekolah, pembelian peralatan pendidikan dan sebagainya.

2. Kesihatan seperti pembelian mesin dialisis, peralatan perubatan dan rawatan.

3. Pelaburan dana wakaf yang akan diuruskan oleh Muamalat Invest Sdn. Bhd.

Muamalat Invest Sdn. Bhd. yang merupakan anak syarikat BBMB adalah sebuah syarikat pengurusan modal akan membuat pelaburan secara profesional di dalam instrumen-intrumen pasaran patuh Shariah bagi menghasilkan keuntungan. Sejumlah 25 peratus daripada hasil pelaburan akan dibahagikan semula kepada PWS dan 75 peratus selebihnya akan diserahkan kepada JPS untuk dibahagikan semula kepada sektor-sektor yang bersesuaian. Dua sektor utama yang menerima manfaat Wakaf Selangor Muamalat ialah kesihatan dan pendidikan khususnya bagi golongan yang kurang berkemampuan samada Muslim atau bukan Islam. Jika ditinjau di dalam sejarah Islam, kedua sektor ini adalah merupakan penerima utama manfaat wakaf. Artinya penyaluran manfaat wakaf kepada orang-orang awam yang kurang berkemampuan akan dapat membantu meringankan beban kos hidup yang ditanggung mereka dan dapat membantu meringankan beban kewangan pihak kerajaan. ${ }^{28}$

\section{Model CW berbasis Bisnis Perusahaan}

Terminologi wakaf perusahaan pertama kali digunakan oleh Johor Corporation (JCorp) yang meluncurkan wakaf perusahaan pada tahun 2006 dengan mewakafkan saham miliknya yang bernilai RM200 juta di dalam anak perusahaannya yaitu Kulim (M) Berhad,

\footnotetext{
${ }^{27} \mathrm{BMMB}, 2012$.

${ }^{28}$ Murat Cizakca, Islamic capitalism and finance: Origins, evolution and the future, Glos: Edward Elgar. (20। la).
} 
KPJ Healthcare Berhad dan Johor Tanah Berhad. ${ }^{29}$ Wakaf An-Nur Corporation (WANCorp) yaitu anak perusahaan JCorp telah dipertanggungjawabkan mengurus wakaf perusahaan yang memberikan fokus kepada aspek kesehatan melalui jaringan Klinik Wakaf An-Nur dan Rumah Sakit Wakaf An-Nur. ${ }^{30}$

Pasien-pasien yang mendapatkan perawatan di klinik dan rumah sakit bersangkutan dikenakan biaya yang minimal yaitu Ringgit Malaysia Lima saja dan pasien-pasien terdiri dari yang beragama Islam dan lain-lain. Selain dari dividen saham-saham yang diwakafkan, WANCORP turut membuka kesempatan kepada individu untuk berwakaf dengan menjadi anggota wakaf korporasi yang mana sebagian biaya anggota diwakafkan. Aspek-aspek pengamalan etika tata kelola perusahaan di dalam manajemen aset wakaf oleh WANCORP dapat dilihat melalui pelaporan Laporan Keuangan Tahunan dan juga pelaporan kegiatan lain.

Model wakaf perusahaan yang dikelola oleh Waqaf An-Nur corporat Berhad (WANCorp) adalah dianggap sebagai model wakaf perusahaan yang pertama di Malaysia. WANCorp adalah merupakan anak perusahaan kepada JCorp dan merupakan perusahaan terbatas yang tidak memiliki kepemilikan saham dan didirikan untuk mengelola aset serta saham JCorp yang telah diwakafkan berpatokan pada prinsip Shariah.

Sebagai sebuah badan perusahaan di bawah JCorp, WANCorp berperan sebagai pelaksana wakaf perusahaan yang didirikan oleh JCorp melalui izin yang diberikan oleh Majlis Agama Islam Johor (MAIJ). Berdasarkan nota kesepahaman (MoU) yang ditandantangani bersama MAIJ dan JCorp pada 4 Desember 2009, MAIJ telah setuju untuk menunjuk WANCorp sebagai "Nazir Khas" saham wakaf dimulai tanggal 11 Juli 2005. WANCorp bertindak sebagai Penerima (mawquf alayh), Manajer dan Administrator aset wakaf disertifikasi oleh MAIJ. Selain itu, WANCorp juga mengimplementasikan Islamic Corporate Social Responsibility (CSR Islam) mewakili JCorp.

${ }^{29}$ JCorp, 2006; Muhammad Ali Hashim, 2011.

${ }^{30}$ Asharaf and Abdullah, 20 I2; Hajah Mustafa et.al, 2009 ; Ab. Shakor, 20II. 
Pada 2006, JCorp telah meluncurkan Wakaf Korporasi dengan memindahkan 12.35 juta unit saham JCorp di Kulim (M) Bhd, 18.60 juta unit saham di KPJ Healthcare Bhd dan 4.32 juta unit saham di Johor Land Ltd ke Grup Waqaf An-Nur Bhd sebagai wali amanat. Konsep ini merupakan strategi penting untuk implementasi misi korporasi JCorp, Jihad Business. Sebagai bukti, melalui agenda korporasi wakaf, di dalam laporan pada tahun 2007 JCorp telah mengalokasikan sejumlah 25 persen dari dividen yang diperoleh dari unit-unit saham terlibat sebagai wakaf. ${ }^{31}$ Oleh karena itu, dividen yang diperoleh dapat digunakan untuk membiayai berbagai manfaat kesejahteraan amal yang menguntungkan komunitas Muslim dan non-Muslim secara keseluruhan.

Sumber keuangan utama WANCorp adalah melalui saham wakaf yang disponsori oleh perusahaan korporat yang terdiri dari beberapa anak perusahaan JCorp. Saham tersebut terdiri dari saham yang terdaftar di Bursa Malaysia dan tidak terdaftar. Perusahaan senaraian yang terlibat di dalam model korporasi wakaf termasuk KPJ Healthcare Berhad, Kulim (M) Berhad dan Al-Aqar KPJ REIT. Sementara perusahaan yang tidak terdaftar seperti Tiram Travel Sdn Bhd, Aspirasi Akses Sdn Bhd dan TPM Managament Sdn Bhd.

Penyaluran manfaat wakaf juga dibuat berdasarkan dokumen Argumen Wakaf yang menyatakan bahwa 70 persen dari akan diinvestasikan kembali, 25 persen akan disalurkan untuk tujuan kebajikan ( $f$ i sabilillah) dan 5 persen disumbangkan kepada MAIJ. ${ }^{32}$ Sejumlah 70 persen hasil wakaf akan diinvestasikan dalam investasi deposito tetap lembaga keuangan patuh shariah dan pembelian Saham Dana Johor. Sementara manfaat wakaf yang sebesar 25 persen akan disalurkan untuk membiayai tiga bentuk program kebajikan yaitu:

i. Program Kesejahteraan (55\%) yang meliputi sumbangan kepada aspek kesehatan, masjid, surau, organisasi publik, anak yatim, brigade wakaf dan proyek CSR yang lain.

\footnotetext{
31 JCorp, 2007

32 WANCorp, 201 I; Johor Corporation, 2008; KWANB, 2007; WANCorp, 2010.
} 
ii. Proyek Spesifik (35\%) adalah proyek khusus WANCorp yang melibatkan biaya yang besar seperti proyek bersama orang asli pada tahun 2011 dan Teater Imam Bukhari pada tahun 2010.

iii. Pengembangan Sumber Daya Manusia, Pendidikan dan Kewirausahaan (10\%) pula berupa pembiayaan pembiayaan konferensi, pelatihan kepada mutawif, buku, pinjaman tanpa bunga, beasiswa dan lain-lainbagi manfaat wakaf 5 persen bagi MAIJ, sejumlah RM718, 076 telah diserahkan kepada MAIJ pada tahun 2011.

\section{Gambar Model Bisnis Wakaf Korporasi}

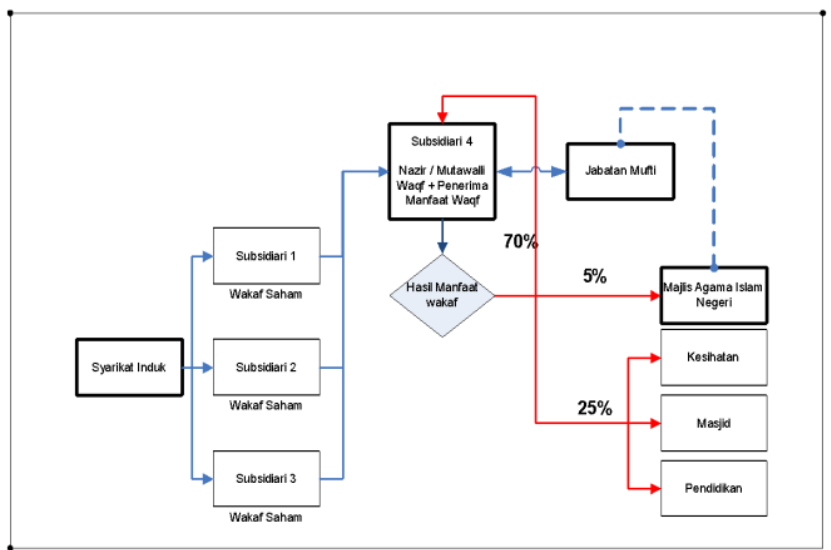

Sumber: Modifikasi Asharaf \& Abdull, 2014

Berdasarkan Gambar di di atas, entitas korporasi dapat didirikan sebagai anak perusahaan atau anak perusahaan untuk mengelola kegiatan wakaf sebagaimana dilakukan oleh JCorp. Pada saat yang sama, anak perusahaan juga merupakan Nazir dan penerima aset wakaf sekaligus hasil wakaf. Mengacu kepada JCorp, 70 persen hasil manfaat wakaf disalurkan kepada Waqaf An-Nur Corporation Berhad yang kemudian menyalurkannya kembali kepada penerima-penerima akhir. 


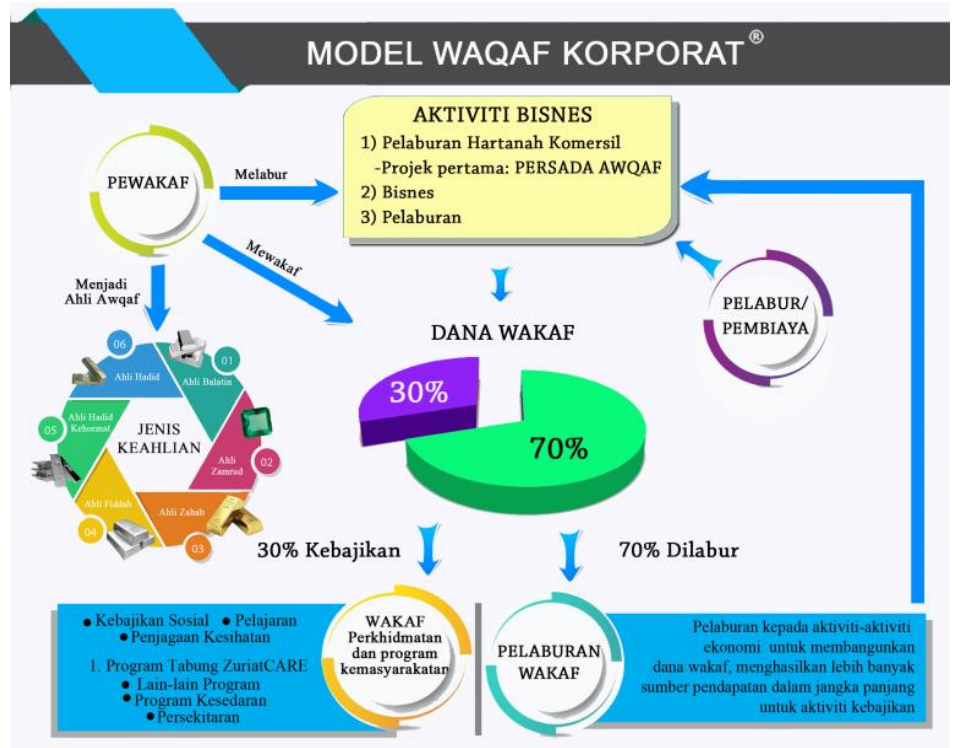

Sementara Awqaf holdings memberikan ciri yang sedikit berbeda dengan Jcorp terkait wakaf korporasi.

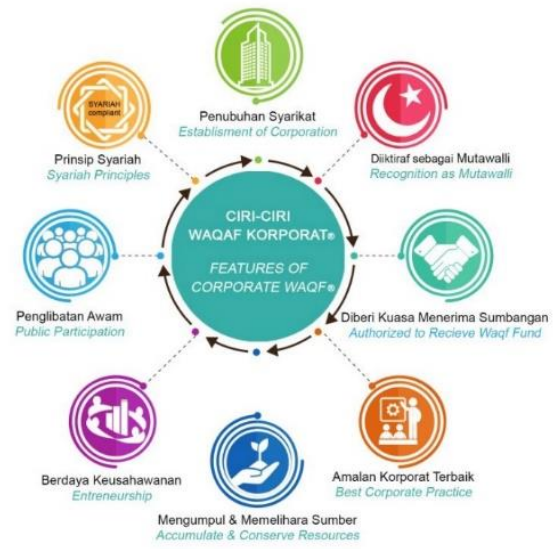

Terkait model wakaf bisnis korporasi, di Indonesia sebenarnya sudah banyak lembaga yang mulai menerapkan, namun masih belum komprehensif dan belum dapat menjalankan model korporasi secara integral. Beberapa contoh diantaranya 
misalnya: ${ }^{33}$ Tabung Wakaf Indonesia (TWI), Yayasan Wakaf Bangun Nurani Bangsa (YWBNB), Wakaf Al-Azhar, Rumah Wakaf Indonesia (RWI), Global Wakaf Corporation (GWC), Yayasan Al Khairaat, dan beberapa bisnis sejenis. ${ }^{34}$

Model-model wakaf korporasi yang tumbuh dan masih beragam tersebut setidaknya perlu disinergikan dan diintegrasikan dengan model wakaf Jcorp dan Awqaf yang memiliki skema yang sangat komprehensif dan integral. Termasuk pada wilayah pengawasannya, dengan adanya auditor independent. Sehingga mampu melahirkan praktik-praktik model wakaf yang komprehensif di Indonesia.

\section{Model CW berbasis Bisnis Universitas}

Fitur wakaf perusahaan yang memberikan fleksibilitas kepada pihak pewakaf sebagai manajer dan juga penerima manfaat wakaf telah menarik perhatian universitas untuk mendirikan dana wakaf untuk menghasilkan pendapatan berikutnya membiayai skema beasiswa dan juga biaya operasional lembaga tersebut. Kebutuhan pembiayaan alternatif bagi universitas amatlah mendesak terutama ketika pihak pemerintah telah mengurangi alokasi tahunan sekitar 10-20 persen kepada universitas publik mulai dari tahun 2016. ${ }^{35}$ Ada beberapa universitas negeri yang telah menerapkan skema wakaf seperti UIAM, UKM, UPM dan USIM. Pendirian dan manajemen wakaf di universitas dikelola badan wakaf yang berperan untuk mengumpulkan, mengelola, berinvestasi dan menyalurkan manfaat kepada penerima. Saat ini, sebagian besar penerima adalah siswa yang menerima manfaat wakaf dalam bentuk beasiswa. ${ }^{36}$

Beberapa universitas telah menubuhkan dana wakaf masingmasing seperti UIAM, UKM, UPM dan USIM. Bagi tujuan ilustrasi amalan model universiti wakaf korporat, Berikut model wakaf yang diterapkan USIM.

\footnotetext{
${ }^{33}$ Rozalinda, 20 I 5; Hosen, 2016 dan Muljawan et. al, 2016.

34 Muljawan, et al, 2016.

35 Zulkahiri, 2016.

${ }^{36}$ Asharaf dan Mustafa, 2013.
} 


\section{Gambar Model Wakaf Korporat Universitas (USIM)}

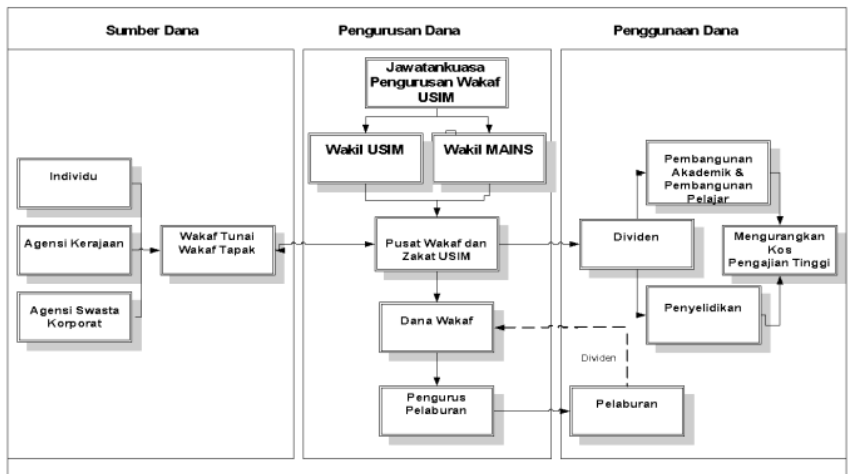

Sumber: Modifikasi Asharaf \& Abdullaah, 2014.

USIM telah dilantik sebagai mutawwali khas oleh pihak Majlis Agama Islam Negeri Sembilan yang membawa kepada pelembagaan Wakaf Al-Abrar USIM pada tahun 2013. Bagi tujuan pengelolaan aset wakaf, Pusat Wakaf dan Zakat USIM telah dilembagakan bertanggungjawab mengurus dan menyalurkan manfaat wakaf kepada penerima. Terdapat dua kategori produk wakaf yang diuruskan oleh Pusat Wakaf dan Zakat USIM yaitu skema wakaf tunai dan skema wakaf tapak. Tiada had minima ditetapkan bagi sumbangan wakaf tunai, namun bagi wakaf tapak pula RM10 dan RM50 ditetapkan bagi pembelian satu lot bagi pembelian 3 lot kedai yang menempatkan Klinik Pakar Kesihatan dan Pergigian USIM.

Cara distrubusi Wakaf adalah sebagai berikut: ${ }^{37}$

1. Distribusi dari dana Tabung Pendidikan Wakaf kepada pelajar yang layak dan memerlukan dalam bentuk bantuan kewangan, bantuan peralatan pembelajaran seperti buku teks, dan sebagainya.

2. Dana wakaf yang diperoleh dari Wakaf Tunai, Wakaf lahan dan Tabung Pendidikan tidak akan disatukan. Dana tersebut

${ }^{37}$ USIM, 2017 
akan digunakan untuk tujuan bantuan yang diwakafkan juga ada Wakaf lahan, Wakaf Tunai ataupun Tabung Pendidikan.

3. Hasil keuntungan yang diperolehi untuk pengelolaan harta wakaf seperti sewaan bangunan akan diagihkan secara sistematik kepada pelajar yang layak.

Model bisnis wakaf universitas ini tentu sedikit berbeda dengan yang ada dari sisi manajerialnya, meskipun masing-masing memiliki kelebihan dan kekurangannya. Hal ini dikarenakan masih dilakukan oleh masing-masing lembaga/yayasan universitas tersebut dan belum ada kebijakan yang menaungi secara integral. Misalnya saja hanya dilakukan oleh universitas-universitas swasta dan tidak ada upaya dilakukan universitas negeri. Beberapa model bisnis wakaf korporasi universitas yaitu: ${ }^{38}$ Yayasan Wakaf Universitas Islam Indonesia (UII), Yayasan Wakaf Universitas Muslim Indonesia (UMI), Yayasan Badan Wakaf Sultan Agung Semarang, Yayasan Badan Wakaf Paramadina, dan bisnis universitas sejenis.

\section{Model CW berbasis Bisnis Pesantren}

Agar pesantren mencapai visi dan misinya sebagai bagian dari masyarakat madani, maka pesantren membutuhkan sumbersumber daya/dana dalam menopang tujuan luhurnya. Pesantren wakaf, yaitu pesantren yang dibangun dengan kedermawanan atau filantropi Islam berupa institusi wakaf dipandang cukup tepat sebagai model pengembangan kemandirian pesantren di era Indonesia kontemporer. Proses pengembangan pesantren wakaf dapat dilakukan sebagaimana profil dua pesantren di atas dengan beberapa pilar kekuatan pendorong: 1) Adanya pengorbanan yang dilakukan oleh pendiri dan pengasuh pesantren dengan mewakafkan harta miliknya untuk pesantren, 2) Kelembagan pesantren wakaf profesional dalam bentuk badan hukum/yayasan,

${ }^{38}$ Hosen, 2016, Muljawan, et al., 2016. 
3) Pengelolaan aset-aset wakaf secara produktif, dan 4) Penyaluran hasil wakaf baik untuk internal pesantren maupun masyarakat. ${ }^{39}$

\section{Model Wakaf Korporat Pesantren}

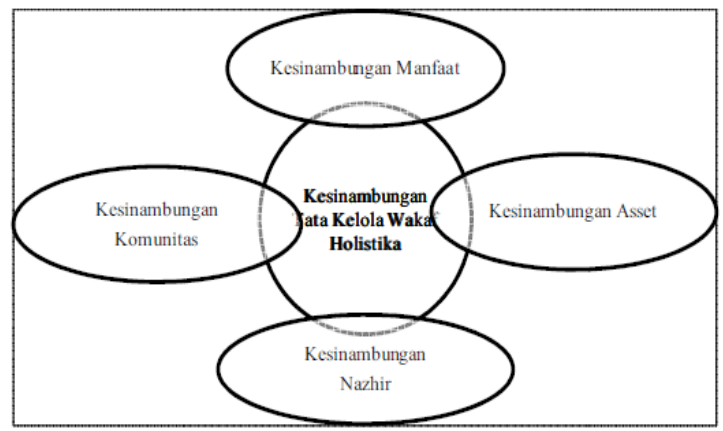

Pilar pertama dan utama adalah adanya suri tauladan yang baik dari para pendahulu dan pimpinan pesantren dengan tulus ikhlas mewakafkan sebagian harta miliknya untuk diperuntukkan bagi kemaslahatan umat, yaitu pengembangan pesantren dan tidak sebaliknya diwariskan kepada anak turunnya. Bukti bahwa Hadratus Syaikh Hasyim Asy'ari mewakafkan sekitar 13 ha tanah untuk asrama pesantren dan sawah pada tahun 1947 sebelum beliau wafat telah memberikan sinyal adanya kepentingan yang lebih luhur dibanding lainnya untuk pengembangan dan kemandirian pesantren pada masa depan. Begitu juga dengan pesantren Gontor dengan upaya yang dilakukan tiga pendiri awal yaitu "Trimurti" untuk berikrar mewakafkan tanah pesantren Gontor kepada masyarakat.

Pilar kedua adalah secara kelembagaan pengelola wakaf pesantren harus dilakukan secara professional dan terbuka. Ini dibuktikan pada kedua pesantren telah menunjukkan nâzir wakaf pesantren berupa yayasan atau berbadan hukum yang agaknya berbeda dengan nâzir organisasi atau perorangan dalam mengelola

39 Pondok Pesantren Darussalam Gontor, Warta Dunia Pondok Modern Gontor, Vol. 61 (Sya'ban, I429 H), 48-49. 
wakaf. Nadjib dan al- Makassary menyebutkan beberapa kelebihan nâzir yayasan dalam pengelolaan wakaf, di antaranya: pertama, lebih responsif dan implementatif ketika menerima model-model manajemen modern dalam wakaf baik dalam transparansi keuangan, pengambilan kebijakan wakaf, administrasi wakaf, rencana kerja, pergantian kepengurusan maupun dalam mengembangkan aset wakaf dan sumber daya nâzir. Kedua, memiliki kekuatan hukum yang pasti karena disyahkan oleh notaris atau pejabat yang berwenang. Ketiga, sebagai solusi praktis atas adanya konflik kepesantrenan yang bisa saja muncul di kemudian hari. Keempat, ke depan nâzir yayasan dipandang sebagai model ideal dalam kelembagaan pengelolaan wakaf. Yayasan Hasyim Asy'ari PP. Tebuireng dan Badan Wakaf PMDG Ponorogo dengan Yayasan Perluasan dan Pengembangan Wakaf Pondok Modern (YPPWPM) Gontor telah membuktikan bahwa nâzir yayasan dalam mengelola wakaf lebih tepat dan akseptebel di lingkungan masyarakat pesantren.

Pilar ketiga adalah dengan melakukan pengelolaan wakaf secara produktif. Hal ini dicontohkan sangat menarik dalam menggalang wâqif baru berupa perusahaan oleh nâzir wakaf Tebuireng, karena ada program penanaman tanaman sengon pada tanah wakaf pesantren dan untuk memproduktifkannya, maka nâzir wakaf Pesantren Tebuireng berkerja sama dengan salah satu perusahan asal Pasuruan yang konsen terhadap penanaman pohon Sengon ini dan bisa disepakati. Begitu juga dalam program intensifikasi pertanian di wakaf Tebuireng juga berlangsung baik. Sedangkan dalam badan wakaf Gontor, kerjasama dengan perusahaan pernah dilakukan dan contoh yang terakhir adalah tahun 2008 melalui YPPWPM membuka lahan dan menanam kelapa Sawit di Jambi. YPPWPM telah membeli tanah hak milik adat (yang telah lama dimiliki oleh seorang pengusaha) di lokasi yang berada di daerah Jambi dengan luas 300 ha milik Pondok Modern Gontor. Tanah tersebut dibeli oleh Badan Wakaf Gontor secara tunai. Sistem pengelolaan lahan tersebut, dilakukan dengan pola kerjasama borongan, dengan seorang pengusaha yang telah 
memiliki izin usaha dan mampu mengelola secara profesional. Pola tersebut disepakati dengan perjanjian awal, bahwa pihak pengelola ataupun pemborong bersedia untuk mengganti biaya garap, jika ternyata di kemudian hari mengalami kegagalan panen atau tidak berubah.

Strategi pengembangan produktivitas pengelolaan wakaf di kedua pesantren juga dilakukan dengan cara membangun unit usaha ekonomi produktif dari harta wakaf yang menghasilkan pendapatan bagi pesantren. Pengembangan pendapatan dilakukan lewat penjualan produk, pelayanan jasa profesional, penyewaaan sarana dan prasarana fasilitas, pengembangan dana abadi dan investasi dari harta-harta wakaf yang ada. Nâzir wakaf Tebuireng telah melaksanakan program seperti ini seperti pemberdayaan aset wakaf berupa sawah dan tanah dengan mencoba meningkatkan hasil dengan berbagai model produktivitas daya wakaf. Begitu juga dengan program sengonisasi dan dilahirkannya Perseroaan Terbatas (PT) atas nama Pesantren Tebuireng yang pada intinya bertugas mengembangkan sumber dana wakaf pesantren. Untuk wakaf Pondok Gontor banyak sekali usaha yang telah dilakukan seperti menggarap sawah dengan sistem bagi hasil, investasi melalui unit-unit usaha produktif dan penggalangan dana dengan pola langsung. Usaha paling baru yang dilakukan wakaf Gontor adalah mengembangkan tanaman buah Naga. Buah Naga menjadi salah satu pilihan untuk dikembangkan oleh bagian pertanian YPPWPM di lahan kering yang belum termanfaatkan secara maksimal. Penanaman buah Naga, pada tahap awal ini, memanfaatkan lahan seluas kurang lebih $750 \mathrm{~m} 2$, dengan menggunakan sarana pendukung yang lazim digunakan untuk menanam dan mengembangkan buah Naga. Khusus untuk unit usaha produktif, wakaf Gontor sampai tahun 2009, telah mendayakan 30 ragam usaha.

Pilar keempat yaitu dari hasil pengelolaan aset wakaf maka disalurkan untuk kepentingan masyarakat, baik secara internal untuk pemberdayaan pesantren dalam mengembangkan misi utama pesantren, maupun secara eksternal untuk pemberdayaan 
masyarakat umum. Pada posisi penyaluran hasil wakaf baik untuk tujuan internal pesantren maupun eksternal, maka pada titik inilah independensi, kemandirian dan kesinambungan pesantren dalam menjalankan misinya bisa diukur pencapaiannya..$^{40}$

Bentuk contoh lain dari praktik bisnis pesantren terkait pengelolaan wakaf yaitu, yayasan Al Khairaat. Sebuah yayasan yang bergerak di bidang pendidikan Islam dan berpusat di kota Palu, Sulawesi Tengah. Yayasan Al Khairaat mengelola sejumlah harta wakaf tanah. Pada tahun 1999, terdata ada 17 lokasi tanah wakaf di Kecamatan Palu Barat. Sementara itu, di Kabupaten Posos terdata 46 lokasi. Secara umum, tanah wakaf yang dikelola Al Khairaat luasnya bervariasi, mulai dari $90 \mathrm{~m} 2$ hingga 50 ha. Sebaran tanah wakaf Al Khairaat sendiri berada di (i) Kota Palu sekitar 48.4 persen dari seluruh tanah wakaf di Kota Palu; (ii) Kabupaten Donggala sekitar 10.33 persen; dan (iii) Kabupaten Parigi Moutong sekitar 29.89 persen.

\section{Penutup}

Dari keseluruhan uraian yang telah dikemukakan dalam babbab terdahulu dapat disimpulkan sebagai berikut:

Pertama, Model pengelolaan dan pengembangan aset-aset wakaf perusahaan di beberapa negara khususnya di Malaysia dan Singapura memiliki model yang khas, Di Awqof Holding BHD Selangor Misalnya, mutawali adalah MAIN Negeri Sembilan bentuk model wakaf korporasinya adalah Pengembangan Perusahaan melalui proyek Awqaf Persada. Sementara Pada Jcorp melalui Johor Annur Corporation, Mutawalinya adalah MAIN Johor dan bentuk pengembangan model wakaf korporasinya adalah Social Entreneurship. Selanjutnya pada Waqf Real Estate Singapore (WAREES), MUTAWALInya dipegang oleh MUIS Singapore, sementara model wakaf korporasinya adalah Best Corporate Practice.

\footnotetext{
40 Miftahul Huda, "Wakaf dan Kemandirian Pesantren: Dari Tebuireng Hingga Gontor," Islamica, Vol 7 No I, (September 20 I2). 2I2-23I
} 
Kedua, rancangan model-model pengembangan wakaf perusahaan untuk Indonesia yang sesuai dengan konteks hukum wakaf Indonesia dan kearifan tradisi yang telah berkembang adalah badan usaha, bank, universitas, yayasan, rumah sakit, koperasi. Sehingga untuk mewujudkan penguatan model wakaf korporasi holistik di Indonesia diperlukan penguatan pada pemangku regulasi sekaligus pemahaman yang integratif dan holistik di kalangan ulama.

Rekomendasi yang peneliti tawarkan terkait penelitian ini, yaitu: Pertama, perlu adanya upaya penguatan dari sisi pemahaman dan keputusan ulama serta pemangku regulasi tentang wakaf perusahaan di Indonesia, karena hingga hari ini belum adanya keselarasan pandangan terkait praktik wakaf perusahaan. Kedua, wakaf perusahaan dapat menjadi alternatif strategis dalam upaya percepatan pembangunan ekonomi nasional, serta meningkatkan sosio-ekonomi umat Islam dalam pelbagai sektor seperti pendidikan, kesehatan dan sosial.

\section{Daftar Pustaka}

Ascarya, "Merancang Model-model Wakaf Produktif"., https://archive.act.id/id., akses, 20 Agustus 2017.

Aula, Muhammad Abbas. "Artikel Pemberdayaan Umat Melalui Lembaga Wakaf," http://bwi.or.id/index.php?, diakses 14 Agustus 2017.

Cizakca, Murat. Islamic capitalism and finance: Origins, evolution and the future, Glos: Edward Elgar. (2011a).

Corporation, Johor. Johor Corporation: Corporate Waqf Concept (Konsep Waqaf Korporat), Johor Bahru: Johor Corporation \& Kumpulan Waqaf An-Nur Berhad, (2008).

Gontor, Pondok Pesantren Darussalam. Warta Dunia Pondok Modern Gontor, Vol. 61 Sya'ban, 1429 H.

Hoexter, Miriam. Charity, The Poor, and Distribution of Alms in Ottomon Algiers, dalam Tuti A. Najib dan Ridwan alMakassary, ed., Tuhan, dan Agenda Kemanusiaan, Studi Tentang Wakaf dalam Perspektif Keadilan Sosial di Indonesia, 
Jakarta: Center for the Study of Religion and Culture (CSRS) Universitas Islam Negeri Syarif Hidayatullah, Desember 2006.

Huda, Miftahul. "Wakaf dan Kemandirian Pesantren: Dari Tebuireng Hingga Gontor," Islamica, Vol 7 No 1. September 2012.

Huda, Miftahul. Mengalirkan Manfaat Wakaf, Depok: Gramata Publishing, 2015.

Indonesia, Kementerian Agama Negara Republik. Model Penggembangan Wakaf Produktif, Jakarta; Direktorat Wakaf, 2008.

Indonesia, Kementerian Agama Negara Republik. Paradigma Baru Wakaf di Indonesia, Jakarta: Direktorat Pemberdayaan Wakaf, 2008.

Jalil, Abdullah. dan Ramli, Asharaf Mohd. Funding Higher Education In Malaysia: Corporate Waqf Model, Waqf Workshop: Contemporary Role of Higher Education, Alor Star: AlBukhari International University. (2013)

Jalil, Abdullah. dan Ramli, Asharaf Mohd. "Conceptualisation of Corporate Waqf" (2014), http://ddms.usim.edu.my. 318, Akses pada 20 Agustus, 2018.

Jamal, Ahmad Muhammad 'Abd al-Azim. Daur Nizam Al Waqf alIslami fi Tanmiyah al-Iqtishadiyah al Mu'ashirah, Qahirah: Dar as-Salam, 2007.

Kabisi (al), Muhammad Abid Abdullah., Hukum Wakaf, Jakarta: IIMaN Press, 2004.

Memorandum AWQAF dan Ciri-ciri Waqaf Korporat, awqaf.com..my. diakses pada 6 Agustus 2018.

Mohsin, Magda Ismail Abdel. Cash Waqf: A New Financial Product, Petaling Jaya: Prentic Hall-Pearson, 2009.

Mohsin, Magda Ismail Abdel. Corporate Waqf And Its Role In The Different Societies, The 2nd InternationalConference on Islamic Economics and Economies of the OIC Countries (ICIE 2013), Kuala Lumpur. 2013. 
Ramli, Asharaf Mohd. \& Jalil, Abdullaah. "Banking Model of Corporate Waqf: An Analysis of Wakaf Selangor Muamalat", Paper presented at the International Accounting and Business Conference (IABC), Persada Johor, Johor Bahru, (2013).

Ramli, Asharaf Mohd. \& Jalil, Abdullaah. "Corporate Waqf Model and Its Distinctive Features: The Future of Islamic Philanthropy" (2013, 4 - 5 December).

Sulaeman, "Model Investasi Wakaf Melalui Sukuk Musyarakah: Studi Kasus Negara Singapura", Forum Riset Ekonomi dan Keuangan Syariah IV (2015). 